\title{
ROSIGLITAZONE-INDUCED CHANGES IN THE OXIDATIVE STRESS METABOLISM AND FATTY ACID COMPOSITION IN RELATION WITH TRACE ELEMENT STATUS IN THE PRIMARY ADIPOCYTES
}

\author{
PROMENE UZROKOVANE ROSIGLITAZONOM U METABOLIZMU OKSIDATIVNOG STRESA \\ I SASTAVU MASNIH KISELINA U ODNOSU NA STATUS ELEMENATA U TRAGOVIMA \\ U PRIMARNIM ADIPOCITIMA
}

\author{
Duygu Aydemir 1,2, Ehsan Sarayloo 1,2, Nuriye Nuray Ulusu 1,2 \\ ${ }^{1}$ Koç University, School of Medicine, Rumelifeneri Yolu, Sariyer, 34450, Istanbul, Turkey \\ ${ }^{2}$ Koç University Research Center for Translational Medicine (KUTTAM), Sariyer, Istanbul, Turkey
}

\begin{abstract}
Summary
Background: Metabolic syndrome, obesity and type 2 diabetes are metabolic disorders characterized by the insulin resistance and the impairment in the insulin secretion. Since impairment in the oxidative stress and adipocyte metabolism contribute to the formation of obesity and diabetes, targeting adipose tissue can be considered as an effective approach to fight against them. Rosiglitazone is used for treatment for patients with type 2 diabetes via inducing lipogenesis and transdifferentiation of white adipose tissue into brown adipose tissue. Since the development of such therapeutics is required to control the formation and function of brown fat cells, we aimed to reveal possible molecular mechanisms behind rosiglitazone induced biochemical changes in the adipose tissue.

Methods: Cells were expanded in the adipocyte culture medium supplemented with $5 \mu \mathrm{g} / \mathrm{mL}$ insulin following 2 days' induction. After those cells were treated with rosiglitazone $0,0.13 \mathrm{~mol} / \mathrm{L}$ and $10 \mu \mathrm{mol} / \mathrm{L}$ rosiglitazone for 48 hours and at $8^{\text {th }}$ day, cells were collected and stored at $-80{ }^{\circ} \mathrm{C}$. Then the cells were used to evaluate antioxidant enzyme activities, mineral and trace element levels and fatty acid composition.

Results: Glucose-6-phosphate dehydrogenase and glutathione reductase significantly reduced in rosiglitazonetreated groups compared to the control. $\mathrm{Na}, \mathrm{Mg}, \mathrm{K}, \mathrm{Ca}, \mathrm{Cr}$,
\end{abstract}

\section{Kratak sadržaj}

Uvod: Metabolički sindrom, gojaznost i dijabetes tip 2 su metabolički poremećaji za koje je karakteristična otpornost na insulin i poremećaj lučenja insulina. S obzirom da poremećaj oksidativnog stresa i metabolizma adipocita doprinosi gojaznosti i dijabetesa, ciljanje masnog tkiva se može smatrati efikasnim pristupom u borbi protiv njih. Rosiglitazon se koristi za lečenje pacijenata sa dijabetesom tipa 2 putem indukcije lipogeneze i transdiferencijacije belog masnog tkiva u mrko masno tkivo. Pošto je razvoj takvih terapija potreban za kontrolu stvaranja i funkcije mrkih masnih ćelija, želeli smo da otkrijemo moguće molekularne mehanizme koji stoje iza biohemijskih promena masnog tkiva izazvanih rosiglitazonom.

Metode: Ekspanzija ćelija je vršena u medijumu za adipocitnu kulturu dopunjenom sa $5 \mu \mathrm{g} / \mathrm{mL}$ insulina nakon indukcije od 2 dana. Nakon što su te ćelije tretirane rosiglitazonom 0 , $0,13 \mathrm{~mol} / \mathrm{L}$ i $10 \mu \mathrm{mol} / \mathrm{L}$ rosiglitazona tokom 48 sati, osmog dana ćelije su sakupljene i čuvane na $-80^{\circ} \mathrm{C}$. Zatim su ćelije korišćene za procenu antioksidativnih enzimskih aktivnosti, nivoa minerala i elemenata u tragovima i sastava masnih kiselina.

Rezultati: Glukoza-6-fosfat dehidrogenaza i glutation reduktaza su značajno smanjene u grupama tretiranim rosiglitazonom u poređenju sa kontrolom grupom. $\mathrm{Na}, \mathrm{Mg}, \mathrm{K}, \mathrm{Ca}$, $\mathrm{Cr}, \mathrm{Fe}, \mathrm{Ni}, \mathrm{Cu}, \mathrm{Zn}, \mathrm{Rb}, \mathrm{Sr}, \mathrm{Cs}, \mathrm{Ba}$ i Pb su određeni u ćelijskim

Address for correspondence:

N. Nuray Ulusu

Koc University, School of Medicine

Rumelifeneri Yolu, Sariyer, Istanbul, Turkey

Phone: +90 (212) 3381160

Fax: +90 (212) 3381168

e-mail: nulusu@ku.edu.tr 
$\mathrm{Fe}, \mathrm{Ni}, \mathrm{Cu}, \mathrm{Zn}, \mathrm{Rb}, \mathrm{Sr}, \mathrm{Cs}, \mathrm{Ba}$ and $\mathrm{Pb}$ were determined in the cell lysates via ICP-MS. Also, relative FAME content decreased in the rosiglitazone-treated groups compared to the control.

Conclusions: Rosiglitazone treatment at low doses showed promising results which may promote brown adipose tissue formation.

Keywords: rosiglitazone, oxidative stress, trace elements, minerals, fatty acid

\section{Introduction}

Adipose tissue stores and/or releases fatty acids (FAs) depends on the need of the energy requirement of organisms since adipocytes are the main regulators of energy and glucose homeostasis $(1,2)$. White adipose tissue (WAT) and brown adipose tissue (BAT) are types of adipose tissue and coexist in mammals. WAT is responsible for energy storage in the form of triacylglycerol where BAT burns triglycerides to generate energy called as thermogenesis and decrease significantly by maturation in human. Thus, impairment in the adipose tissue function causes several diseases, including obesity, type II diabetes mellitus (T2DM), cardiovascular diseases and cancer $(3,4)$.

Rosiglitazone (RSG) is one of the drugs used for patients with type 2 diabetes to reduce insulin resistance and hyperglycemia via decreasing blood glucose levels. Also, this drug induces adipose differentiation, triglyceride storage (TG) and lipogenesis (5-7). Moreover, RSG induces transdifferentiation of WAT into BAT via increasing mitochondrial mass and lipid oxidation. In this concept, developing drugs which enhance BAT formation or conversion of WAT into BAT is considered as an important strategy to fight against obesity and T2DM $(1-4,8,9)$.

T2DM, metabolic syndrome and obesity are characterized by the insulin resistance and the impairment in the insulin secretion which both are tightly associated with the impairment in the adipose tissue functions, and increased levels of reactive oxygen species (ROS) termed as oxidative stress $(10-18)$. Oxidative environment induces ROS to attack lipids leading to both lipid peroxidation and lipotoxicity that cause adipocyte dysfunction. Impairment in the adipocyte homeostasis results in the excessive release of free fatty acid (FFA) which are transported to the distant tissues, including liver, muscle or pancreatic cells and cause toxic effects in the target organs. Therefore, targeting adipose tissue can be an effective method to prevent diabetes, T2DM and metabolic syndrome $(8,19,20)$. Development of such therapeutics requires significant knowledge of the molecular mechanisms controlling the formation and function of brown fat cells (7). Therefore, in this study, we aimed to investigate fatty acid composition, lizatima preko ICP-MS. Takođe, relativni sadržaj FAME se smanjio u grupama tretiranim rosiglitazonom u poređenju sa kontrolom grupom.

Zaključak: Tretman rosiglitazonom u malim dozama pokazao je obećavajuće rezultate koji mogu pospešiti stvaranje mrkog masnog tkiva.

Ključne reči: rosiglitazon, oksidativni stres, elementi u tragovima, minerali, masna kiselina

oxidative stress metabolism and their relation to the trace and mineral levels to reveal molecular mechanisms which control BAT into WAT conversion.

\section{Materials and Methods}

\section{Materials}

Protease inhibitor cocktail was obtained from Sigma-Aldrich (Germany). Glucose-6-phosphate (G6P), sodium phosphate monobasic and dibasic, 6-phosphogluconate (6-PG), reduced nicotinamide adenine dinucleotide phosphate $\left(\mathrm{NADPH}+\mathrm{H}^{+}\right.$), oxidized glutathione (GSSG), glutathione reductase (GR), reduced glutathione $(\mathrm{GSH})$, sodium azide, hydrogen peroxide $\left(\mathrm{H}_{2} \mathrm{O}_{2}\right)$ and ethylenediaminetetraacetic acid (EDTA), nicotinamide adenine dinucleotide phosphate $\left(\mathrm{NADP}^{+}\right)$, magnesium chloride $\left(\mathrm{MgCl}_{2}\right)$, Tris [Tris (hydroxymethyl) aminomethane] were purchased from Sigma-Aldrich (USA). Chemicals and organic solvents used for lipid analysis were obtained as HPLC grade. Hexane, $65 \% \mathrm{HNO}_{3}$ of SUPRAPUR ${ }^{\circledR}$ grade, methanol and $\mathrm{HCl}$ were purchased from Merck (Germany). C4-C24 FAME mix standard solution and methyl tricosanoate were obtained from SigmaAldrich (USA) and used for FAME quantification, identification and as internal standard, respectively.

\section{Methods}

\section{Preparation of primary white adipocyte culture}

30-35 days-old male mice were used to obtain inguinal stroma-vascular (SV) fractions. SV cells were grown, and adipocyte differentiation was performed as described by Serkan et al. (21). Cells were expanded in the adipocyte culture medium supplemented with $5 \mu \mathrm{g} / \mathrm{mL}$ insulin following two days induction. Starting at day 6 , cells were grown in adipocyte culture medium in the following conditions $0,0.1$ $3 \mathrm{~mol} / \mathrm{L}$ and $10 \mu \mathrm{mol} / \mathrm{L}$ rosiglitazone for 48 hours, and at day 8 , cells were collected and stored at $-80{ }^{\circ} \mathrm{C}$ until experiments. 


\section{Preparation of cell lysates}

Cells were scraped off in $1 \mathrm{~mL}$ PBS and then transferred into $1 \mathrm{~mL}$ centrifuge tubes. Samples were centrifuged at $2000 \mathrm{rpm}$ for 5 minutes, and then cell pellets were suspended in the $200 \mathrm{mmol} / \mathrm{L}$ sodium phosphate buffer $(\mathrm{pH}$ 7.4) containing protease inhibitor cocktail and sonicated for 10 seconds on the ice. Afterwards, samples were centrifuged at 14,500 rpm for 25 minutes at $4{ }^{\circ} \mathrm{C}$ and stored at $-80{ }^{\circ} \mathrm{C}$ freezer until experiments.

\section{Glucose-6-phosphate dehydrogenase (G6PD) activity}

The assay mixture was prepared with $10 \mathrm{mmol} / \mathrm{L}$ $\mathrm{MgCl}_{2}, 0.6 \mathrm{mmol} / \mathrm{L} \mathrm{G} 6 \mathrm{P}$ and $0.2 \mathrm{mmol} / \mathrm{L} \mathrm{NADP}^{+}$in $100 \mathrm{mmol} / \mathrm{L}$ Tris/HCl buffer ( $\mathrm{pH}$ 8.0). G6PD activity was evaluated spectrophotometrically by following NADPH production at $340 \mathrm{~nm}$ and $37^{\circ} \mathrm{C}$ (22). The required amount of G6PD enzyme to reduce one $\mathrm{mmol} \mathrm{NADP}^{+} / \mathrm{min}$ under the indicated assay conditions was used to define one unit (U) of activity. Specific G6PD enzyme activity was represented as the number of units/mg protein.

\section{6-phosphogluconate dehydrogenase (6-PGD) activity}

6-Phosphogluconate dehydrogenase activity (G6PD) was determined by the same method as described above for the G6PD. Only, $0.6 \mathrm{mmol} / \mathrm{L}$ 6G6P was substituted for $0.6 \mathrm{mmol} / \mathrm{L} 6-\mathrm{PG}$ as a substrate in the assay mixture (23).

\section{Glutathione reductase (GR) activity}

Modified Staal method was used to evaluate GR activity at $37{ }^{\circ} \mathrm{C}$ spectrophotometrically. The incubation mixture was prepared with $200 \mathrm{mmol} / \mathrm{L}$ sodium phosphate buffer (pH 7.4), $1 \mathrm{mmol} / \mathrm{L}$ GSSG, 0.2 $\mathrm{mmol} / \mathrm{L} \mathrm{NADPH}$ and cell lysate as enzyme source. The decrease in the absorbance at $340 \mathrm{~nm}$ was monitored for 60 seconds (24).

\section{Glutathione-S-transferase (GST) activity}

Glutathione-S-transferase enzyme activity was determined by measuring the conjugation of GSH with 1-chloro-2, 4-dinitrobenzene (CDNB) as described by Habig et al. (25). The activity was followed for 30 seconds at $37^{\circ} \mathrm{C}$.

\section{Glutathione peroxidase (GPx) activity}

Incubation mixture contained $200 \mathrm{mmol} / \mathrm{L}$ potassium phosphate buffer ( $\mathrm{pH} 7.4), \mathrm{GR}$ enzyme (10 U/mL), $400 \mathrm{mmol} / \mathrm{L}$ sodium azide, $200 \mathrm{mmol} / \mathrm{L}$
EDTA, $100 \mathrm{mmol} / \mathrm{L}$ GSH, $2 \mathrm{mmol} / \mathrm{L} \mathrm{NADPH}, 5 \mu \mathrm{L}$ tissue lysate and completed to $500 \mu \mathrm{L}$ with double distilled water (26). Samples were incubated for 10 $\min$ at $37^{\circ} \mathrm{C}$, and then the reaction was initiated by the addition of $5 \mu \mathrm{L}$ of $10 \mathrm{mmol} / \mathrm{L} \mathrm{H}_{2} \mathrm{O}_{2}$. Afterwards, GPx activity was measured spectrophotometrically for 30 seconds at the room temperature.

\section{Protein determination}

BCA method was used to determine protein concentrations of the samples by using Spectramax M2 microplate reader. The assay was performed with the Pierce $^{\mathrm{TM}}$ BCA Protein Assay Kit by following instructions (27).

\section{ICP-MS Analysis}

Cell lysates were diluted by a factor of 10 in $65 \%$ $\mathrm{HNO}_{3}$ of SUPRAPUR ${ }^{\circledR}$ grade. Trace and mineral element levels were determined by using Agilent 7700x ICP-MS (Agilent Technologies Inc., Tokyo, Japan) as described by Aydemir et al. (28).

\section{Transesterification}

In situ acidic direct transesterification (DT) was used for derivatization of fatty acids according to Gomez et al. (29). Briefly, samples were treated with $3 \mathrm{ml}$ methanol with $2 \% \mathrm{HCl}$ for $2 \mathrm{~h}$ at $80^{\circ} \mathrm{C}$. After samples had reached the room temperature, hexane and distilled water were added to the reaction mixture to separate the fatty acid methyl esters (FAMEs).

Fatty acids determination by gas chromatography-mass spectrometry (GC-MS)

Fatty acid methyl esters were analyzed by 7890B Agilent GC equipped with a 5977A Agilent MSD detector and a DB-23 column (60 $\mathrm{m} \times 0.25 \mathrm{~mm} \times$ $0.25 \mu \mathrm{m}$ film thickness). $1 \mu \mathrm{L}$ FAME extract was used from each sample. The splitless mode was applied, and the injector temperature was set up to $250{ }^{\circ} \mathrm{C}$. Helium was used as the carrier gas at $50^{\circ} \mathrm{C}$ and 180 $\mathrm{kPa}(33 \mathrm{~cm} / \mathrm{S})$. The column temperature was increased from $50{ }^{\circ} \mathrm{C}$ to $175^{\circ} \mathrm{C}$ at $25^{\circ} \mathrm{C}$ per min and then from $175^{\circ} \mathrm{C}$ to $235^{\circ} \mathrm{C}$ at $4{ }^{\circ} \mathrm{C}$ per min, and the detector temperature was $250^{\circ} \mathrm{C}$.

\section{Statistical Analysis}

All data were analyzed by GraphPad Prism, and one-way analysis of variance (ANOVA) followed by a Tukey's post hoc test for multiple comparisons for comparison data sets. All data were represented as the mean \pm standard deviation (SD). 


\section{Results}

Anti-oxidant enzyme activities

G6PD, GR and GPx activities decreased in the RSG treated cells compared to the control, however, this decrease was not significant for GPx activity. On the other hand, there was not a substantial change in the GST and 6-PGD activities (Figure 1, Table I).

\section{Trace element and mineral levels}

$\mathrm{Na}, \mathrm{Mg}, \mathrm{K}, \mathrm{Ca}, \mathrm{Cr}, \mathrm{Fe}, \mathrm{Ni}, \mathrm{Cu}, \mathrm{Zn}, \mathrm{Rb}, \mathrm{Sr}, \mathrm{Cs}, \mathrm{Ba}$ and $\mathrm{Pb}$ were determined in the cell lysates via ICPMS. Ca and Mg levels significantly decreased in the $0.1 \mu \mathrm{mol} / \mathrm{L}$ RSG treated groups compared to the 1 $\mu \mathrm{mol} / \mathrm{L}$ treated ones. Also, $\mathrm{K}$ concentrations increased in the RSG-treated groups compared to the control, where $\mathrm{Na}$ levels significantly decreased in control and $0.1 \mu \mathrm{mol} / \mathrm{L}$ RSG treated groups compared to the $1 \mu \mathrm{mol} / \mathrm{L}$ treatment groups (Figure 2).
Table I Anti-oxidant enzyme activities in control and rosiglitazone treated cells.

\begin{tabular}{|l|c|c|c|}
\hline \multirow{2}{*}{ Enzyme } & \multirow{2}{*}{ Control } & \multicolumn{2}{|c|}{ Rosiglitazone } \\
\cline { 3 - 4 } & & $0.1 \mu \mathrm{mol} / \mathrm{L}$ & $1 \mu \mathrm{mol} / \mathrm{L}$ \\
\hline $\begin{array}{l}\text { G6PD, } \\
\text { U/mg protein }\end{array}$ & $3.53 \pm 0.2$ & $1.742 \pm 0.6^{\mathrm{ba}}$ & $1.816 \pm 0.04^{\mathrm{b}}$ \\
\hline $\begin{array}{l}\text { 6-PGD, } \\
\mathrm{U} / \mathrm{mg} \text { protein }\end{array}$ & $0.84 \pm 0.17$ & $0.68 \pm 0.25$ & $0.96 \pm 0.19$ \\
\hline $\begin{array}{l}\text { GST, } \\
\text { U/mg protein }\end{array}$ & $1.8 \pm 0.2$ & $0.9 \pm 0.2$ & $1.05 \pm 0.06$ \\
\hline $\begin{array}{l}\text { GR, } \\
\mathrm{U} / \mathrm{mg} \text { protein }\end{array}$ & $1.25 \pm 0.15$ & $1.33 \pm 0.23^{\mathrm{c}}$ & $1.05 \pm 0.18^{\mathrm{d}}$ \\
\hline $\begin{array}{l}\text { GPx, } \\
\text { U/mg protein }\end{array}$ & $1.83 \pm 0.3$ & $1.37 \pm 0.4$ & $1.05 \pm 0.16$ \\
\hline
\end{tabular}

All results were given as mean $\pm \mathrm{SD}$. ${ }^{a}$ different from control $(p=0.0004),{ }^{b}$ different from control $(p=0.0005),{ }^{c}$ different from control $(p=0.0003)$, ${ }^{d}$ different from control $(p=0.001)$.

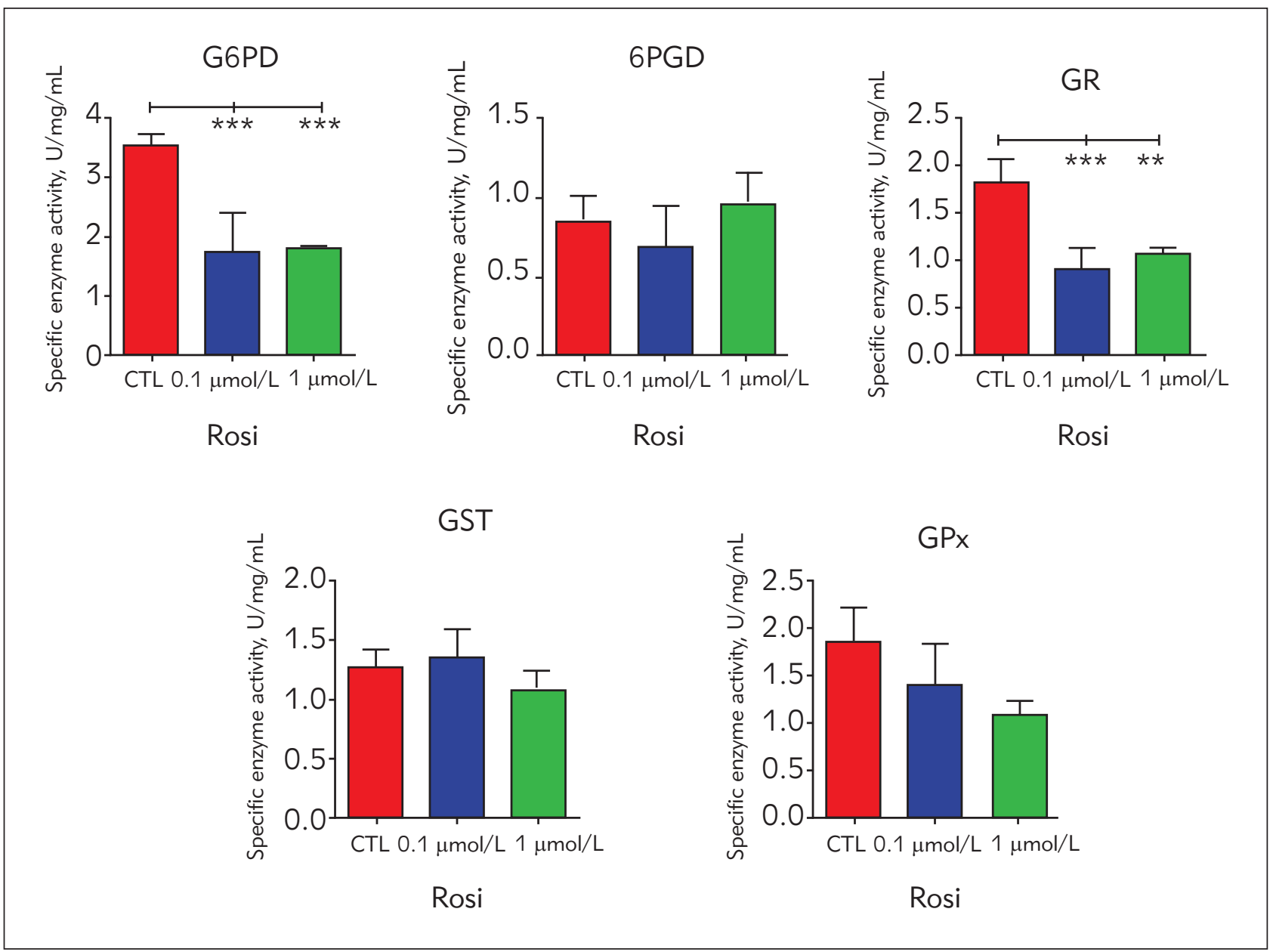

Figure 1 Anti-oxidant enzyme activities in control and rosiglitazone treated cells. All results were given as mean \pm SD. a different from control $(p=0.0004)$, b different from control $(p=0.0005)$, c different from control $(p=0.0003)$, d different from control $(p=0.001)$. 


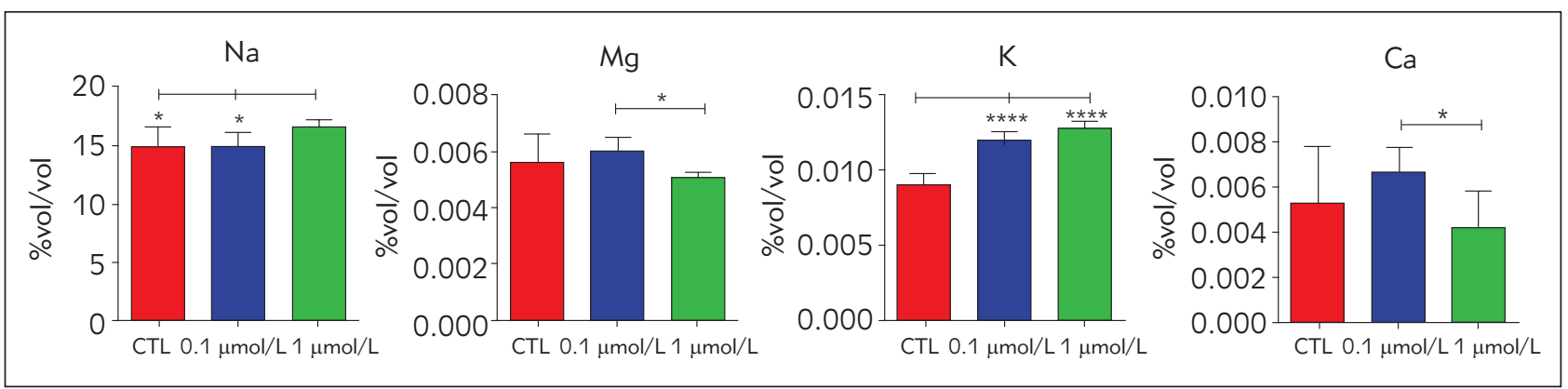

Figure 2 Mineral levels in control and rosiglitazone-treated groups. All results were given as mean \pm SD. ${ }^{*} p<0.05$, ** $p<0.01$ and $* * * p<0.001$.

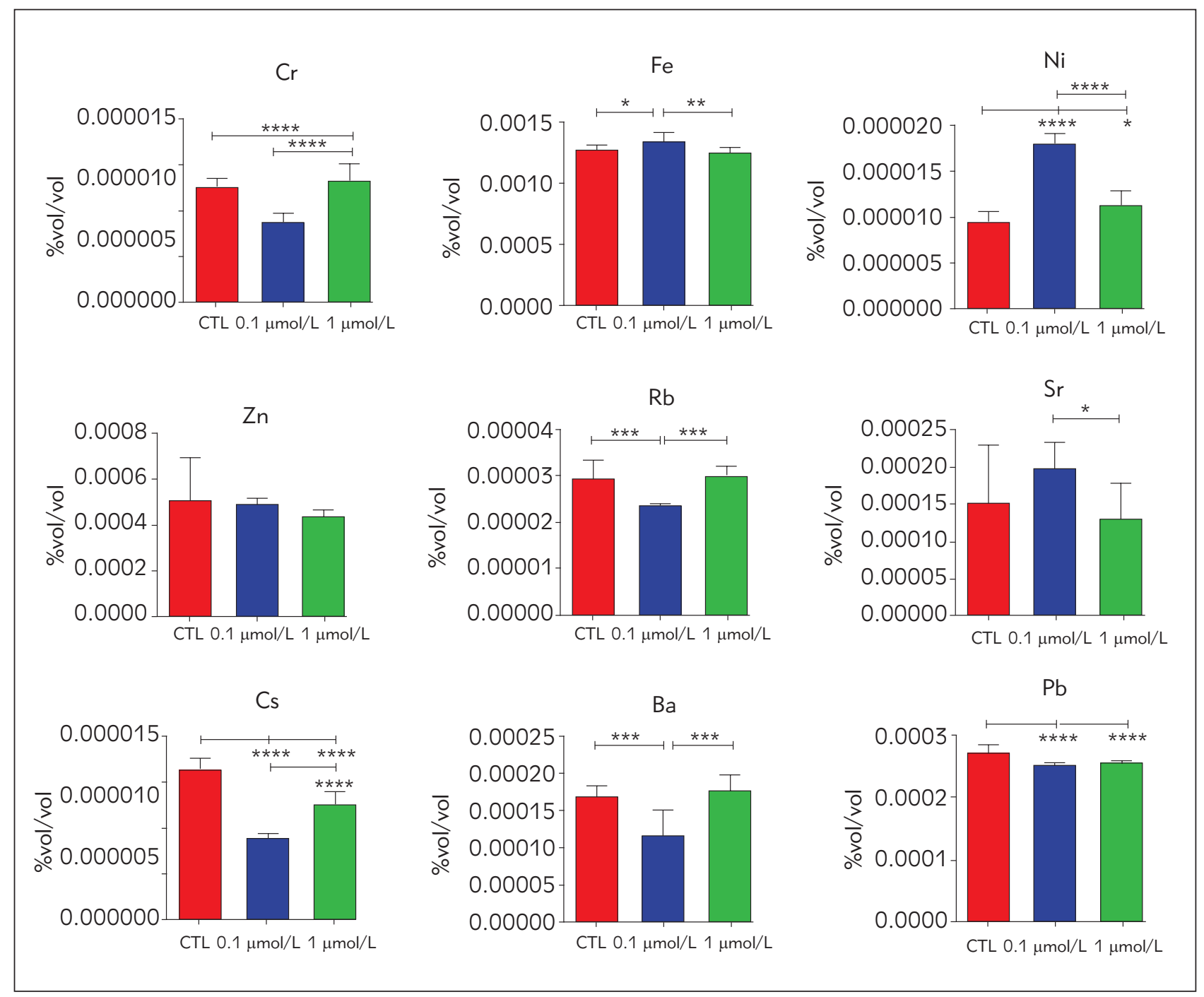

Figure 3 Trace element levels in control and rosiglitazone-treated groups. All results were given as mean $\pm S D .{ }^{*} p<0.05, * * p$ $<0.01$ and ${ }^{* * *} \mathrm{p}<0.001$.

On the other hand, $\mathrm{Ba}$ and $\mathrm{Rb}$ levels significantly decreased in $0.1 \mu \mathrm{mol} / \mathrm{L}$ dosage groups compared to the other groups, where Fe levels elevated considerably. $\mathrm{Pb}, \mathrm{Cs}$ and $\mathrm{Zn}$ concentrations decreased in the
RSG treated groups in comparison with the control. $\mathrm{Sr}$ and $\mathrm{Ni}$ levels had their peaks in $0.1 \mu \mathrm{mol} / \mathrm{L}$ RSG treated groups, where Cs had peak concentration in $1 \mu \mathrm{mol} / \mathrm{L}$ RSG dosage groups (Figure 3). 


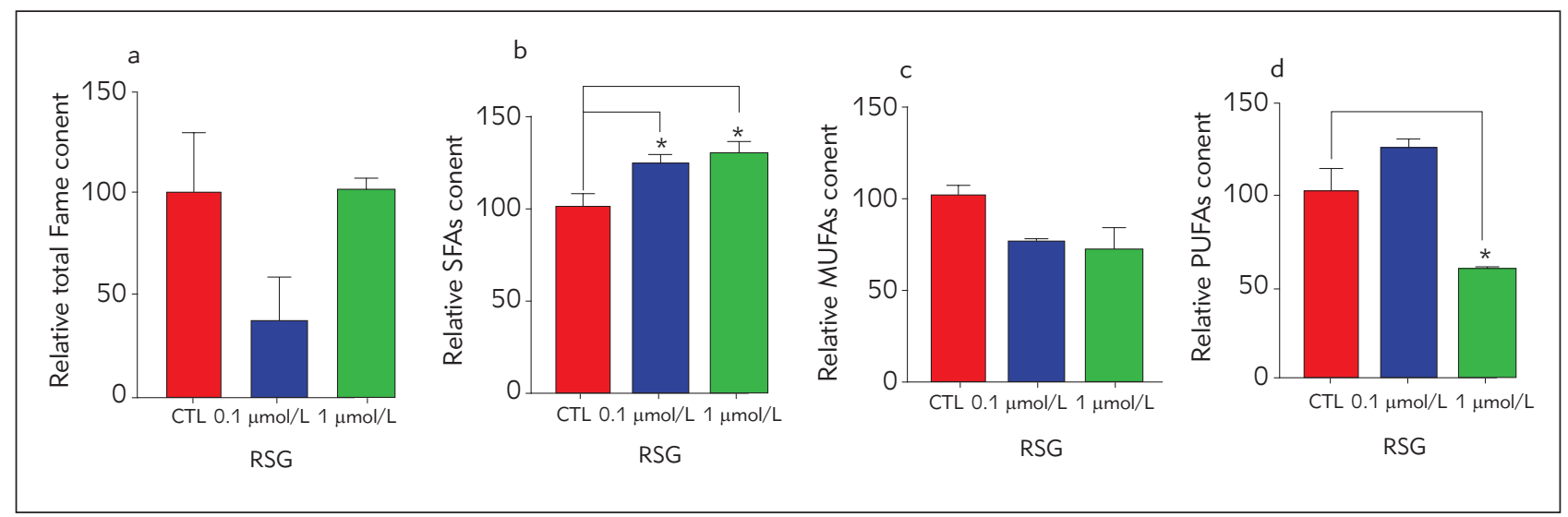

Figure 4 The relative amount of total fatty acid content, saturated fatty acids (SFAs), monosaturated fatty acids (MUFAs) and polyunsaturated fatty acids (PUFAs) of cells treated with $0.1 \mu \mathrm{mol} / \mathrm{L}$ and $1 \mu \mathrm{mol} / \mathrm{L}$ of rosiglitazone. Total peak areas and FAME composition (\% of total FAME) of samples were measured. First, the fold change was calculated between control and rosiglitazone-treated samples, and then the percentage change for each was calculated after setting the amount in control as $100 \%$. All results were given as mean $\pm \mathrm{SD}$. ${ }^{*} \mathrm{p}<0.05$ and ${ }^{* *} \mathrm{p}<0.01$.

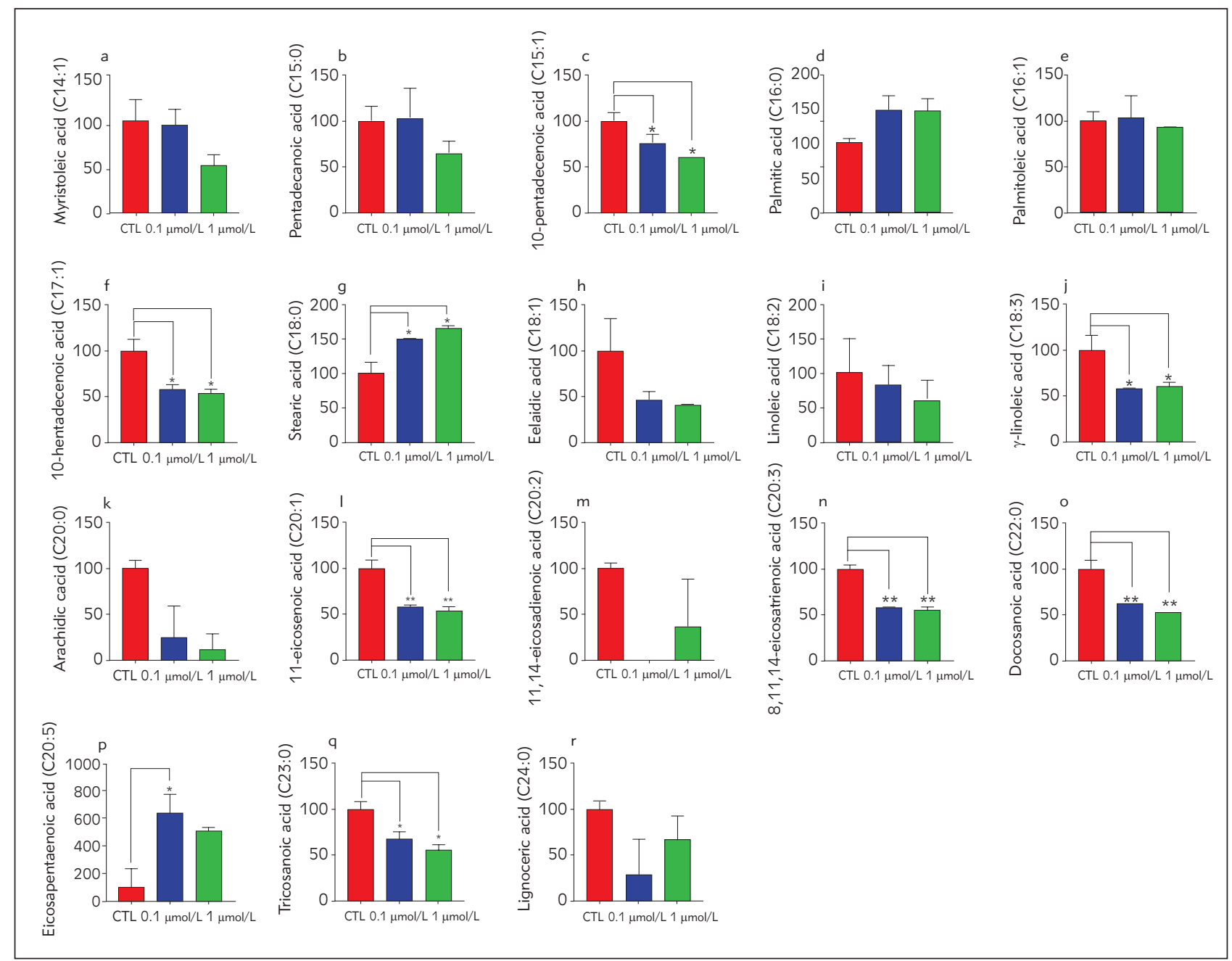

Figure 5 Relative amount individual and total fatty acid content of cells treated with $0.1 \mu \mathrm{mol} / \mathrm{L}$ and $1 \mu \mathrm{mol} / \mathrm{L}$ of rosiglitazone. Total peak areas and FAME composition (\% of total FAME) of samples were measured. First, the fold change was calculated between control and rosiglitazone-treated samples, and then the percentage change for each was calculated after setting the amount in control as $100 \%$. All results were given as mean \pm SD. ${ }^{*} \mathrm{p}<0.05$ and ${ }^{* *} \mathrm{p}<0.01$ 


\section{FAME analysis}

Relative FAME content decreased in RSG-treated groups compared to the control (Figure 4a) and relative saturated fatty acid (SFAs) content significantly increased in RSG treated groups compared to the control (Figure 4b-d). Myristoleic acid, 10-pentadecenoic acid, linoleic acid, elaidic acid, 10-heptadecenoic acid, $\gamma$-linoleic acid, arachidic acid, 11eicosenoic acid, pentadecanoic acid, palmitic acid, palmitoleic acid, stearic acid, 8, 11, 14-eicosatrienoic acid, docosanoic acid, eicosapentaenoic acid, tricosanoic acid and lignoceric acid were detected in the control and RSG-treated groups (Figure 5). All detected fatty acids decreased in RSG dosage groups compared to the control, except palmitic, stearic and eicosapentaenoic acid. However, all changes were not significant (Figure 5a-r). On the other hand, most abundant fatty acids were palmitic and stearic acid in all groups (Figure 5).

\section{Discussion}

Metabolic disorders, T2DM and obesity are characterized by the impairment in the insulin secretion, sensitivity and adipose tissue function. Moreover, both oxidative stress and lipid metabolism play a significant role in the pathogenesis of these diseases and targeting fat tissue can be considered as a good strategy to treat these diseases. Rosiglitazone is used to treat T2DM via reducing insulin resistance and hyperglycemia, also inducing the conversion of WAT into BAT $(2,7,12,16,20)$. Revealing the molecular mechanism behind the transdifferentiation of WAT into BAT is required to fight against diabetes and obesity. Therefore, in our study, we investigated the antioxidant enzyme activity, mineral and trace element levels and fatty acid composition in RSG-treated adipocytes.

G6PD, GR and GPx activities decreased in RSGtreated groups compared to the control (Figure 1, Table I). G6PD is the rate-limiting enzyme of the pentose phosphate pathway (PPP) and responsible for cellular NADPH production involving in the fatty acid analysis. Also, G6PD contributes to the maintenance of the redox status of the cells via production of the NADPH contributing to the GR activity which converts oxidized glutathione (GSSG) into reduced glutathione (GSH). On the other hand, GPx involves in the formation of the GSSG by using GSH. Therefore, according to our data, RSG treatment reduces G6PD activity, NADPH synthesis, GR and GPx activities $(30,31)$.

Afterwards, we evaluated mineral and trace element levels in control and RSG-treated samples. Our data showed that $\mathrm{Ca}^{+2}$ levels significantly increased in the $0.1 \mu \mathrm{mol} / \mathrm{L}$ RSG treatment compared to the 1 $\mu \mathrm{mol} / \mathrm{L}$ group (Figure 2). Elevated calcium levels are known to induce thermogenesis, and $0.1 \mu \mathrm{mol} / \mathrm{L}$ RSG treatment may trigger thermogenesis in adipocytes via $\beta$-AR signalling (32). ATP-sensitive potassium ( $\mathrm{K}_{\text {ATP }}$ ) channels play a vital role in the insulin secretion via depolarization of the cell membrane that leads to the $\mathrm{Ca}^{+2}$ influx in the cell, causing insulin secretion. Inhibition of ATP-sensitive potassium (K $K_{\text {ATP }}$ ) channels by RSG was reported before (33). Our data showed that $0.1 \mu \mathrm{mol} / \mathrm{L}$ RSG treatment induced increased $\mathrm{Ca}$ and $\mathrm{K}$ levels in the cells that may show inducing the insulin secretion (Figure 2). On the other hand, $\mathrm{Mg}$ is essential for glycolysis, citric acid cycle, increasing insulin sensitivity and improving lipid profile (34-38). We showed that 0.1 $\mu \mathrm{mol} / \mathrm{L}$ RSG treatment caused an increase in magnesium concentrations that may be explained by the necessity of $\mathrm{Mg}$ in the cells to improve insulin sensitivity and the lipid profile (Figure 2).

Concentrations of various trace elements including cadmium, chromium, iron, nickel, silver, caesium, lead, rubidium and zinc were investigated in patients with T2DM. Increased $\mathrm{Cr}$ and $\mathrm{Zn}$ levels were reported in T2DM patients $(39,40)$. Also, we showed decreased $\mathrm{Cr}$ and $\mathrm{Zn}$ levels in the cells upon 0.1 $\mu \mathrm{mol} / \mathrm{L}$ RSG treatment (Figure 3). Furthermore, increased levels of heavy metals such as arsenic, zinc and lead are known by their contribution to diabetes via acting like endocrine-disrupting chemicals (39, 41). We showed that $\mathrm{Pb}$ levels significantly decreased in RSG treated groups compared to the control, which can be considered as a positive response against T2DM risk upon RSG treatment (Figure 3). Li et al. reported that $\mathrm{Ni}$ has protective effects against diabetes and increased $\mathrm{Cs}$ and $\mathrm{Ba}$ levels were correlated with the risk of diabetes (41). We showed that RSG treatment increased cellular $\mathrm{Ni}$ levels and decreased $\mathrm{Cs}$ and $\mathrm{Ba}$ levels that compromise previous data.

Furthermore, we investigated total FAME and fatty acid composition in RSG treated and control groups. Our data have revealed that $0.1 \mu \mathrm{mol} / \mathrm{L}$ RSG treatment reduced relative FAME content, where $1 \mu \mathrm{mol} / \mathrm{L}$ treatment did not show any change in the FAME content (Figure 4a). We showed that relative eicosapentaenoic acid content significantly increased in $0.1 \mu \mathrm{mol} / \mathrm{L}$ RSG treated group compared to the control (Figure 5p). Eicosapentaenoic acid is a PUFA which enhances insulin sensitivity and thermogenesis (42). On the other hand, 18-carbon fatty acids including stearic and oleic acid were reported as metabolic modifiers via in vivo studies since they increase the thermogenic capacity of WAT $(43,44)$. The relative content of both stearic acid and oleic acid increased in RSG-treated cells compared to the control according to our data that may show the contribution of RSG to the conversion of WAT into BAT (Figure 5).

According to our data, tricosanoic acid, 11eicosenoic acid, 11,14-eicosadienoic acid, docosanoic acid, 10-heptadecenoic, 10-pentadecenoic 
acid and $\gamma$-linolenic acid significantly decreased upon RSG treatment compared to the control (Figure 5). Since there is no publishing data related to indicated fatty acid concerning oxidative stress and mineral and trace elements, their impact on brown fat tissue and thermogenesis should be further investigated.

Overall, RSG treatment reduced G6PD and GR enzymes contributing to the oxidative stress and fatty acid metabolism. Also, RSG treatment improves trace element and mineral levels that enable restoring of insulin resistance and BAT formation. Relative FAME content reduced upon RSG treatment and relative content of some fatty acids which promote BAT formation increased. Thus the influence of fatty acid composition and types on the BAT formation should be further investigated.

\section{Conclusion}

Adipose tissue is considered as a target for the treatment of insulin resistance and diabetes. RSG is used for the treatment of T2DM and induces transd-

\section{References}

1. Arner P, Langin D. Lipolysis in lipid turnover, cancer cachexia, and obesity-induced insulin resistance. Trends Endocrinol Metab 2014; 25: 255-62. doi: 10.1016/ j.tem.2014.03.002.

2. Perry RJ, Camporez JG, Kursawe R, Titchenell PM, Zhang D, Perry CJ, et al. Hepatic acetyl CoA links adipose tissue inflammation to hepatic insulin resistance and type 2 diabetes. Cell 2015; 160: 745-58. doi: 10.1016/j.cell.2015.01.012.

3. Tiraby C, Tavernier G, Lefort C, Larrouy D, Bouillaud F, Ricquier $D$, et al. Acquirement of brown fat cell features by human white adipocytes. J Biol Chem 2003; 278: 33370-6.

4. Nedergaard J, Bengtsson T, Cannon B. Unexpected evidence for active brown adipose tissue in adult humans. Am J Physiol Endocrinol Metab 2007; 293: E444-52.

5. Teboul L, Gaillard D, Staccini L, Inadera H, Amri EZ, Grimaldi PA. Thiazolidinediones and fatty acids convert myogenic cells into adipose-like Cells. J Biol Chem 1995; 270: 28183-7.

6. Akbay E, Ulusu NN, Töröner F, Ayvaz G, Taneri F, Aktürk $M$, et al. Effects of rosiglitazone treatment on the pentose phosphate pathway and glutathione-dependent enzymes in liver and kidney of rats fed a high-fat diet. Curr Ther Res Clin Exp. 2004; 65: 79-89. doi: 10.1016/S0011393X(04)90007-0.

7. Farmer SR. Molecular determinants of brown adipocyte formation and function. Genes Dev 2008; 22: 1269-75. doi: $10.1101 /$ gad.1681308.

8. Ayala A, Muñoz MF, Argüelles S. Lipid peroxidation: production, metabolism, and signaling mechanisms of malondialdehyde and 4-hydroxy-2-nonenal. Oxid Med Cell Longev 2014; 2014: 360438. doi: 10.1155/2014/ 360438. ifferentiation of WAT into BAT via increasing mitochondrial mass and lipid oxidation. Therefore, the development of therapeutics targeting adipocytes requires information about the molecular mechanisms controlling the formation and function of brown fat cells. RSG treatment on the adipocytes at low doses showed promising results which may address conversion of WAT into BAT. However, the impact of fatty acids on the brown fat formation should be further investigated.

Acknowledgement. We thank Dr Serkan KIR for primary mouse adipocytes. The authors gratefully acknowledge the use of the services and facilities of the Koc University Research Center for Translational Medicine (KUTTAM) and Koc University Tupras Energy Center (KUTEM).

\section{Conflict of interest statement}

The authors state that they have no conflicts of interest regarding the publication of this article.

9. Guéraud F, Atalay M, Bresgen N, Cipak A, Eckl PM, Huc $\mathrm{L}$, et al. Chemistry and biochemistry of lipid peroxidation products. Free Radic Res 2010; 44: 1098-124. doi: 10.3109/10715762.2010.498477.

10. Gerhold DL, Liu F, Jiang G, Li Z, Xu J, Lu M, et al. Gene expression profile of adipocyte differentiation and its regulation by peroxisome proliferator-activated receptorgamma agonists. Endocrinology 2002; 143: 2106-18.

11. Jiang G, Dallas-Yang Q, Li Z, Szalkowski D, Liu F, Shen $X$, et al. Potentiation of insülin signaling in tissues of Zucker obese rats after acute and longterm treatment with PPARY agonists. Diabetes 2002; 51: 2412-9.

12. Mayerson AB, Hundal RS, Dufour S, Lebon V, Befroy D, Cline GW, et al. The effects of rosiglitazone on insulin sensitivity, lipolysis, and hepatic and skeletal muscle triglyceride content in patients with type 2 diabetes. Diabetes 2002; 51: 797-802.

13. Wilson-Fritch L, Burkart A, Bell G, Mendelson K, Leszyk $J$, Nicoloro S, et al. Mitochondrial biogenesis and remodeling during adipogenesis and in response to the insulin sensitizer rosiglitazone. Mol Cell Biol 2003; 23: 108594.

14. Wilson-Fritch L, Nicoloro S, Chouinard M, Lazar MA, Chui PC, Leszyk J, et al. Mitochondrial remodeling in adipose tissue associated with obesity and treatment with rosiglitazone. J Clin Invest 2004; 114: 1281-9.

15. Ozdemir S, Tandogan B, Ulusu NN, Turan B. Angiotensin II receptor blockage prevents diabetes-induced oxidative damage in rat heart. Folia Biol (Praha) 2009; 55: 11-6.

16. Roberts CK, Hevener AL, Barnard RJ. Metabolic syndrome and insulin resistance: underlying causes and modification by exercise training. Compr Physiol 2013; 3: 1-58. doi: 10.1002/cphy.c11006 
17. He H, Tao H, Xiong $\mathrm{H}$, Duan SZ, McGowan FX Jr, Mortensen RM, et al. Rosiglitazone causes cardiotoxicity via peroxisome proliferator-activated receptor $\mathrm{Y}$-independent mitochondrial oxidative stress in mouse hearts. Toxicol Sci 2014; 138: 468-81. doi: 10.1093/toxsci/kfu015.

18. Ulusu NN, Gok M, Erman B, Turan B. Effects of Timolol Treatment on Pancreatic Antioxidant Enzymes in Streptozotocin-induced Diabetic Rats: An Experimental and Computational Study. J Med Biochem 2019; 38: 306-316. doi: 10.2478/jomb-2018-0034. eCollection 2019 Jul.

19. Uchida K. 4-Hydroxy-2-nonenal: a product and mediator of oxidative stress. Prog Lipid Res 2003; 42: 318-43.

20. Cusi K. The role of adipose tissue and lipotoxicity in the pathogenesis of type 2 diabetes. Curr Diab Rep 2010; 10: 306-15. doi: 10.1007/s11892-010-0122-6.

21. Kir S, White JP, Kleiner S, Kazak L, Cohen P, Baracos VE, et al. Tumour-derived PTH-related protein triggers adipose tissue browning and cancer cachexia. Nature 2014; 513: 100-4. doi: 10.1038/nature13528.

22. Betke K, Brewer GJ, Kirkman H, Luzzato L, Motulsky AG, Ramot B, et al. Standardized method for G-6PD assay of haemolysates. WHO Tech Rep Ser 1967: 366; 30-32.

23. Pearse B, Rosemeyer M. 6-phosphogluconate dehydrogenase from human erythrocytes. Methods Enzymol 1975; 41, 220-6.

24. Staal GE, Visser J, Veeger C. Purification and properties of glutathione reductase of human erythrocytes. Biochim Biophys Acta 1969; 185: 39-48.

25. Habig WH, Pabst MJ, Jakoby WB. Glutathione S-transferases. The first enzymatic step in mercapturic acid formation. J Biol Chem 1974; 249: 7130-9.

26. Beutler, E. Red cell metabolism. In: A Manual of Biochemical Methods. Grone \& Stratton, New York 1971, 66-8.

27. Pierce ${ }^{\mathrm{TM}}$ BCA Protein Assay Kit. https://www.thermofisher.com/order/catalog/product/23225.

28. Aydemir D, Karabulut G, im ek G, Gok M, Barlas N, Ulusu NN. Impact of the Di(2-Ethylhexyl) Phthalate Administration on Trace Element and Mineral Levels in Relation of Kidney and Liver Damage in Rats. Biol Trace Elem Res 2018; 186: 474-488. doi: 10.1007/s12011018-1331-0.

29. Castro-Gómez P, Fontecha J, Rodríguez-Alcalá LM. A high-performance direct transmethylation method for total fatty acids assessment in biological and foodstuff samples. Talanta 2014; 128: 518-23. doi: 10.1016/ j.talanta.2014.05.051.

30. Zhang Z, Liew CW, Handy DE, Zhang Y, Leopold JA, Hu $J$, et al. High glucose inhibits glucose-6-phosphate dehydrogenase, leading to increased oxidative stress and beta-cell apoptosis. FASEB J 2010; 24: 1497-505. doi: 10.1096/fj.09-136572

31. Stanton RC. Glucose-6-phosphate dehydrogenase, NADPH, and cell survival. IUBMB Life 2012; 64: 3629. doi: 10.1002/iub.1017.
32. Zhao J, Cannon B, Nedergaard J. 1-Adrenergic Stimulation Potentiates the Thermogenic Action of 3-Adrenoreceptor-generated cAMP in Brown Fat Cells. J Biol Chem 1997; 272: 32847-56.

33. Ashcroft FM. ATP-sensitive potassium channelopathies: focus on insulin secretion. JCI 2005: 115; 2047-58. doi:10.1172/JCl25495

34. Garfinkel L, Garfinkel D. Magnesium regulation of the glycolytic pathway and the enzymes involved. Magnesium 1985; 4: 60-72.

35. Nadler JL, Buchanan T, Natarajan R, Antonipillai I, Bergman R, Rude R. Magnesium deficiency produces insulin resistance and increased thromboxane synthesis. Hypertension 1993; 21: 1024-9.

36. Suárez A, Pulido N, Casla A, Casanova B, Arrieta FJ, Rovira A. Impaired tyrosine-kinase activity of muscle insulin receptors from hypomagnesaemic rats. Diabetologia 1995; 38: 1262-70.

37. Song Y, He K, Levitan EB, Manson JE, Liu S. Effects of oral magnesium supplementation on glycaemic control in type 2 diabetes: a meta-analysis of randomized double-blind controlled trials. Diabet Med 2006; 23: 10506.

38. Shigematsu $M$, Nakagawa $R$, Tomonaga $S$, Funaba $M$, Matsui T. Fluctuations in metabolite content in the liver of magnesium-deficient rats. Br J Nutr 2016: 1-6.

39. Lavicoli I, Fontana L, Bergamaschi A. The effects of metals as endocrine disruptors. J Toxicol Environ Health B Crit Rev 2009; 12: 206-23. doi: 10.1080/ 10937400902902062.

40. Hansen AF, Simić A, Åsvold BO, Romundstad PR, Midthjell K, Syversen $T$, et al. Trace elements in early phase type 2 diabetes mellitus-a population-based study. The hunt study in Norway J Trace Elem Med Biol 2017; 40: 46-53. doi: 10.1016/j.jtemb.2016.12.008.

41. Li XT, Yu PF, Gao Y, Guo WH, Wang J, Liu X, et al., Association between plasma metal levels and diabetes risk: a case-control study in China. Biomed Environ Sci 2017; 30: 482-91 doi: 10.3967/bes2017.064.

42. Li JJ, Huang CJ, Xie D. Anti obesity effects of conjugated linoleic acid, docosahexaenoic acid, and eicosapentaenoic acid. Mol Nutr Food Res 2008; 52: 631-45. doi: 10.1002/mnfr.200700399.

43. Le NH, Shin S, Tu TH, Kim CS, Kang JH, Tsuyoshi G, et al. Diet enriched with Korean pine nut oil improvesmitochondrial oxidative metabolism in skeletal muscle and brownadipose tissue in diet-induced obesity. J Agric Food Chem 2012; 60: 11935-41. doi: 10.1021/jf303548k.

44. Shin S, Ajuwon KM. Divergent Response of Murine and Porcine Adipocytes to Stimulation of Browning Genes by 18 Carbon Polyunsaturated Fatty Acids and Beta Receptor Agonists. Lipids 2018; 53: 65-75. doi: 10.1002/lipd.12010 